\title{
Autobiography as Political Legacy in Transition Periods: Benjamin Franklin and Konrad Adenauer Compared
}

\author{
Volker Depkat
}

University of Regensburg

\section{ABSTRACT}

Developing consciousness of epoch as a category of autobiographical time, the article approaches the autobiographies of Benjamin Franklin and Konrad Adenauer as acts of political communication in historico-biographical transition periods. The temporal semantics of Franklin's and Adenauer's autobiographical texts anchor in a consciousness of epoch, which suggests that (a) the foundations for an anticipated ideal future have been laid through the political decisionmaking of the autobiographer, and that (b) it is uncertain whether the succeeding generations of political decision-makers will continue to pursue the political course that, in the eyes of the autobiographer, will eventually realize the anticipated utopia of an ideal world. The article thus moves away from an understanding of political autobiography as justification of political decisions taken and not taken in the past. Instead, it investigates autobiography as acts of political communication legitimating the past with a future anticipated at the moment of writing the autobiography. This angle sheds light on political autobiography as a future-oriented continuation of politics by autobiographical means. The temporal semantics of the autobiographical text anchoring in a given consciousness of epoch and the communicative functions of the autobiographical act thus extend well beyond the endings of the text and the autobiographer's life.

Keywords: Benjamin Franklin, Konrad Adenauer, political legacy, political autobiography, consciousness of epoch 


\section{ZUSAMMENFASSUNG AUF DEUTSCH}

Epochenbewusstsein als Kategorie autobiographischer Zeit entwickelnd, nähert sich dieser Beitrag den Autobiographien von Benjamin Franklin und Konrad Adenauer als Akten politischer Kommunikation in historisch-biographischen Übergangssituationen. Die temporale Semantik von Franklins und Adenauers Erinnerungen ankern in einem Epochenbewusstsein demzufolge (a) die Grundlagen für eine antizipierte ideale Zukunft durch das politische Handeln des Autobiographen gelegt worden sind, es (b) aber ungewiss ist, ob die nachfolgenden Generationen den politischen Kurs fortführen werden, der nach Meinung des Autobiographen die antizipierte Utopie sicher verwirklichen würde. Mit diesem Ansatz begreift der folgende Aufsatz politische Autobiographie nicht primär als Rechtfertigung vergangenen politischen Entscheidungshandelns. Stattdessen nähert er sich Autobiographie als Akten politischer Kommunikation zur Legitimation der Zukunft. In diesem Licht erscheinen Autobiographien als die zukunftsorientierte Fortsetzung von Politik mit autobiographischen Mitteln. Die in einem jeweils spezifischen Epochenbewusstsein ankernde temporale Semantik des autobiographischen Textes und die kommunikativen Funktionen des autobiographischen Aktes reichen weit über das Ende der Autobiographie und das Leben des Autobiographen hinaus.

Keywords: Benjamin Franklin, Konrad Adenauer, politisches Erbe, politische Autobiographie, Epochenbewusstsein

French theorist Philippe Lejeune's widely accepted definition of autobiography as a '[r] etrospective prose narrative written by a real person concerning his own existence, where the focus is his individual life, in particular the story of his personality' conceptualizes autobiographical texts as an account of a person's past from the perspective of a given present. ${ }^{1}$ It is thus the present in which the act of writing an autobiography is situated that, in defining the meaning and relevance of past experiences, structures both the autobiographical narrative and the interplay of remembering and forgetting it rests on.

While Lejeune's definition suggests that an autobiography is primarily about the past, this article argues that an autobiographical recollection of the past is not to be had without imaginaries of the future that the autobiographer embraces at the time of his autobiographical act. Every given present is, as Reinhart Koselleck and Niklas Luhmann have argued in their theoretical reflections on historical time, structurally linked to both a perceived past and an anticipated future. ${ }^{2}$ If we apply these semantics of historical time to autobiography, then we have to accept that autobiographical texts are not only structured by the interplay of past and 
present but also by that of the present and the future, even if the future is not explicitly thematized in the autobiographical text itself. Therefore, although autobiographies narrate a person's life in retrospect, they are just as much about the future as they are about the past. The temporal semantics of autobiography, therefore, extend well beyond the endings of the text, and they can most certainly extend well beyond the author's forthcoming death.

This holds especially true for political autobiography, i.e. autobiographies of statesmen and political leaders who shaped political and historical developments through decisions taken and not taken - and who struggle to influence political developments even beyond their term in office or their time of influence and power. Much has already been written on political autobiographies as justification of past policies pursued. Otto von Bismarck's Gedanken und Erinnerungen comes to mind, or Winston Churchill's monumental recollections The Second World War, or the many French state memoirs from Louis XIV, Napoleon Bonaparte, or Charles de Gaulle that Pierre Nora investigates into as lieux de mémoire. ${ }^{3}$ This article, however, moves away from political autobiography as justification of the past, and wants to investigate autobiography as acts of political communication legitimating the future. ${ }^{4}$

This function of political autobiography is especially relevant in historical transition periods, i.e. periods when an existing political and social order is replaced by a new one, periods of deep and sustained structural change, either through revolutionary breaks, through evolutionary change, or through defeat in war. To further clarify the concepts of transition period and transformational change in connection with autobiography, it is helpful to introduce the categories of emic and etic that are prevalent in anthropology and behavioral sciences. Emic and etic refer to two different ways of looking at and analyzing historical phenomena from the perspective of the historical actors themselves (emic) and from the perspective of an outsider observer (etic). ${ }^{5}$ Looked at through these categories, transitional change can be categorized as such from an outside perspective that takes political, constitutional or legal changes as indicators, economic transformations, technological innovations, or demographic data and processes. In contrast to that, an emic perspective looks at how change was subjectively seen and experienced by the contemporaries of a given period. The emic perspective suggests that identifying changes as transformational is a matter of perception, and, therefore, highly subjective, often dependent on one's starting base, e.g. his or her political orientation, gender, class, age, or ethnicity.

Autobiography as a narrative instrument for the observation, diagnosis and reflection of change paves paths into the emic perspective on 
transitional change that, however, remains structurally linked to the etic perspective insofar as, on the one hand, the autobiographical observer identifies indicators of structural changes in his own times in his autobiographical text. On the other hand, the very autobiographical act can be triggered and motivated by transitional changes that are not even thematized in the autobiographical itself, as we will see in the further course of this essay. In any case, an autobiography cannot only be an indicator of experienced change, it can also be a factor in ongoing changes insofar as the autobiographer seeks to influence developments beyond the endings of his or her text and his or her time of influence.

The autobiographically diagnosed transitional change that we will encounter in this article was utopia-driven, that is, driven by the anticipation of an ideal world, for which the autobiographer and his political friends, in their view, had laid the foundations through their political decision-making in the past. However, at the moment of the autobiographical act, this envisioned ideal world has not yet materialized, and it is uncertain whether this future will ever materialize. ${ }^{6}$ Seen against this backdrop, autobiographies as political legacies can anchor in a deepseated feeling of uncertainty: the present, in which an autobiography is written, appears to the autobiographer as a time in which the political decisions taken offer the condition of possibility for the utopian future to actually materialize. However, it is uncertain whether the succeeding generations of political decision-makers will continue to pursue the political course that, in the eyes of the autobiographer, will eventually realize the anticipated utopia of an ideal world.

To trace these temporal semantics of political autobiography as political legacy, consciousness of epoch as a category of both historical and autobiographical time is useful. Following the lead of Hans Blumenberg, Reinhart Koselleck and Reinhart Herzog, consciousness of epoch here is defined as a temporal category that relates the temporal dimensions of the past, the present, and the future to each other. ${ }^{7}$ It defines the contemporaries' subjective temporal horizon through which they establish a meaningful relationship between the past, the present, and the future, putting what they experience as new in their own time into a historical perspective. As such a complex category of historical time, consciousness of epoch is in and of itself a cultural fact that binds together analyses of the past, diagnoses of the present, and prognoses of the future.

In light of these theoretical reflections, this article argues that political autobiography can be carried by a consciousness of epoch that transcends the endings of an autobiographer's term of influence, the endings of their autobiographical text, and the end of their life. It is the consciousness of epoch written into and carrying the autobiographical narrative that 
turns political autobiography into acts of political communication intent on shaping and influencing the future.

Unearthing these complex temporal dynamics of political autobiography requires the conscientious biographical and historical contextualization of an autobiographical text, asking when, where, why, and for whom it was written. Embedding an autobiographical text in these contexts lets it appear as a communicative event that can be explained in terms of cause and effect. This is what the following two case studies on Benjamin Franklin's Autobiography and Konrad Adenauer's four-volume Erinnerungen will do in the attempt to explicate the conceptual theses developed above. $^{8}$

It is, of course, reasonable to ask: Why Franklin and Adenauer? They both lived in such different times and circumstances, and their autobiographical texts are so different in and of themselves, that there appears to be little that allows for a comparison. The answer is that they both lived in periods of deep, disruptive, and rapidly accelerating transformational changes that shook existing systems of meaning in their foundations, that invalidated all cognitive maps, and that created a situation of farreaching disorientation about who Americans and Germans were, and who they wanted to be, where they came from, and where they were going. While Adenauer thematizes this situation explicitly in his autobiographical narrative, it is a subtext to Franklin's autobiography that becomes visible only when one relates the autobiographical text to the biographical and historical contexts from which it emerged. Be that as it may, Franklin's and Adenauer's autobiographical narratives both served to provide for collective orientation in a situation of collective disorientation, they both attempted to define notions of national identity substantiated by their own life experiences in a historico-biographical situation where exactly this notion of national identity had become problematic.

\section{PERPETUATING THE AMERICAN EXPERIMENT IN LIBERTY} THROUGH AUTOBIOGRAPHY: BENJAMIN FRANKLIN

Benjamin Franklin was a major player in the revolutionary founding of the United States. ${ }^{9}$ He was the only one to put his signature under the four founding documents of the United States - the Declaration of Independence, the Franco-American Alliance of 1778, the Peace of Paris of 1783, and the draft of the U.S. Constitution. With that record he personified the American Revolution like no other, with the sole exception of George Washington. ${ }^{10}$

Franklin and his fellow revolutionaries saw themselves involved in the creation of a political order to which the highest hopes for human 
liberation were attached. In his seminal revolutionary pamphlet Common Sense, published on January 10, 1776, Thomas Paine urged his countrymen to declare independence immediately. Independence, in Paine's understanding, offered the chance to preserve America 'uncontaminated by European corruption,' and to lay the basis for a political and social order that appeared as ideal under the premises of Enlightenment thinking. 'Should an independancy be brought about,' Paine concluded in an appendix contained in the second edition of Common Sense published in Philadelphia on February 14, 1776, 'we have every opportunity and every encouragement before us, to form the noblest, purest constitution on the face of the earth. [...] The birthday of a new world is at hand. ${ }^{11}$ American independence for Paine thus promised the chance to make the world over and create an order based on natural rights liberalism and the promise of far-reaching self-government and self-determination.

This utopian vision of universal emancipation legitimated revolutionary actions in the present, and it structured the highly complex and complicated history of constitution-making in the newly founded United States. ${ }^{12}$ This is not the place to go into the details of U.S. constitutional history in revolutionary America. Suffice it to say that the American constitutions aimed at institutionalizing the political value system carrying the Declaration of Independence to make the revolution itself permanent. This makes the Declaration of Independence and the republican constitutions drafted and ratified in the 1770s and 1780s related documents of one and the same historical process that aimed at creating a political and social order based on individual freedom and self-government in the widest sense. In the first ever inaugural address of an American president, George Washington, on 30 April 1789, spoke of 'the sacred fire of liberty' kindled by the American Revolution and now in need of constant care and protection. He also referred to 'the republican model of government,' whose destiny would be decided in the United States. For Washington, America's democracy was an 'experiment entrusted to the hands of the American people. ${ }^{13}$

As such an experiment in liberty, the United States were a historical novelty and a radical break with both the theory and history of European republicanism. The world had simply never seen an extended republic based in all of its parts on popular sovereignty, and regulating its political order through a written constitution declaring itself to be the supreme law of the land and the source of all political power. Furthermore, the idea that such a political order should actually expand into space to create what James Madison and other theoretical minds of the U.S. constitution envisioned as an 'extended republic,' was well beyond the wildest dreams of European thinkers and also many American contemporaries. 
The American project of an extended republic based on self-government and widespread popular participation in the decision-making process ran counter to conventional wisdom, which held that self-governed republics could only exist in small political entities like cities or small states like Switzerland or the Netherlands but never in a large and growing state like the United States. Many, therefore, expected that the United States, in wanting to realize self-government in an extended republic, would, in the distant or not so distant future, either fall apart into several smaller republics or develop into a monarchy or some other form of authoritarian government that would destroy individual liberty altogether. To substantiate their argument, contemporaries could point to the ancient Roman republic, which collapsed as it expanded around the Mediterranean, laying the foundations for the monarchic reign of the Caesars. ${ }^{14}$ It is important to note that America's founders were fully aware of these republican traditions, and yet, they decided to create their unprecedented republic of which many believed that it could and would not work.

One major source of anxiety was human nature and especially its passions of pride, ambition, and avarice. They were all seen as dangerous threats to a political and social order built on ideas of individual liberty and self-government. ${ }^{15}$ Passions were dangerous insofar as they could be the source of a destructive egotism that would dissolve all social ties in a republican society. The social anarchy caused by self-centered egotism would destroy the republican order and American liberty with it. Consequently, Franklin's and the other founders' problem was how to stabilize a political order based on liberal principles and individual self-determination, given that human nature, as they perceived it, was a potentially destructive force for this very order.

This is the historical context, in which Benjamin Franklin wrote his autobiography as an exercise in moral self-improvement that was to channel the potentially destructive human passions and turn them into forces supporting and stabilizing the republic. ${ }^{16}$ The project of Franklin's life as represented in his autobiography is about educating human passions to public spirit and love of country, about educating 'an useful citizen.' ${ }^{17}$ Franklin states the central theme of his autobiography right in the opening passages, where he writes:

Having emerg'd from the Poverty and Obscurity in which I was born and bred, to a State of Affluence and some Degree of Reputation in the World, and having gone so far thro' Life with a considerable Share of Felicity, the conducing Means I made use of, which, with the Blessing of God, so well succeeded, my Posterity may like to know, as they may find some of them suitable to their own Situations, and therefore fit to be imitated. ${ }^{18}$ 
Franklin thus narrates his life as a success story that encompasses the rise from 'Poverty and Obscurity' to 'Affluence and some Degree of Reputation,' with many readers and scholars all too often reducing success to the purely material success that anchors in the rise from rags to riches. Franklin's autobiography, therefore, is very often cited as the first manifestation of the American Dream that lets a dishwasher become a millionaire. ${ }^{19}$

This reading of Franklin's autobiography is a great reduction, however, insofar as the rise he presents is actually much more complex. It is as much about reputation as it is about affluence, and this reputation results from both affluence and a virtuous way of life based on industry, frugality, honesty, reliability, humility, etc. The concepts of obscurity and reputation as well as poverty and affluence are inherently related, defining a system of multi-directionally interconnected and mutually reinforcing relationships that lets poverty correspond to obscurity, just as affluence corresponds to reputation. Together these highly complex interrelationships define the patterns of liberty and dependence, felicity and disaster, and power and powerlessness that Franklin elaborates on in his autobiography.

At the core of Franklin's project of self-improvement is morality, as becomes manifest in Part Two of his autobiography, in which he gives a detailed account of the "bold and arduous Project of arriving at moral Perfection. ${ }^{20}$ Drawing on the altogether thirteen moral virtues of Temperance, Silence, Order, Resolution, Frugality, Industry, Sincerity, Justice, Moderation, Cleanliness, Tranquility, Chastity, and Humility, Franklin meticulously describes how he systematically went about acquiring the 'Habitude' of all of them. ${ }^{21} \mathrm{He}$ explains for others to follow how he methodically disciplined himself, elaborating on how he constantly examined his daily conduct, how he measured his progress to perfection, and how he documented it with the help of graphic charts. In this context, he stresses that his project of moral self-perfection was not informed by any religious dogma but driven by the purely secular 'Utility and Excellency' of his method, which in his eyes is universally applicable and 'serviceable to People in all Religions. ${ }^{22}$

Much has been written on Franklin's list of virtues, and one can, of course, see his autobiography as a manual for conditioning an economic man, who works himself up from rags to riches in a free-market democracy. For Max Weber, Franklin's life and autobiographical writings were the purest manifestation of a secularized spirit of capitalism that had emancipated itself from all the religious strings of a Protestant Ethic and its focus on salvation in the next world. In Weber's reading, therefore, Franklin marks the transition from a religiously bound and motivated accumulation of wealth to modern capitalism, in which making money 
becomes an end in itself. ${ }^{23}$ The virtues that Franklin promotes in his autobiography are thus useful and functional in a capitalist economy; conduct based on these values will assure material success.

While the capitalist virtues of Franklin's life and writings have already been written about substantially, much less has been said about the connection between Franklin's catalogue of virtues and republicanism. Instead of primarily wanting to educate economic men, Franklin's autobiography focuses on republican men, whose passions are put to the service of a civil society based on self-government. In this context, it is important to stress that Franklin's memoir presents neither material wealth nor morality as ends in themselves but rather only the means to an end: a life dedicated to public improvement and public service. Franklin's exercise in moral self-improvement was to, first and foremost, channel the potentially destructive human passions and turn them into forces supporting and stabilizing the republic. As a result, Franklin advocated the culture of a voluntarism that connected both individual benefits and the promotion of the common good.

One very telling episode that illustrates how Franklin's model of a 'civic man' joined self-interest and common interest in a habitus of voluntarism can be found in his autobiography, where he comes to speak of the problem of Philadelphia's unpaved streets. ${ }^{24}$ Here, Franklin contrasts the 'beautiful Regularity' of Philadelphia's grid street plan with the 'Disgrace' of these streets being unpaved. When the weather was wet, Franklin writes, the rain would turn them into a morass, 'so that it was difficult to cross them. And in dry Weather the Dust was offensive.' As a result, people either were 'over Shoes in Dirt,' or they could not cross the streets at all when going to the market, which, of course, was detrimental to business.

Franklin himself had his print shop on Market Street, and the problem he described was his own everyday experience. He thus began to write and talk on the subject, using his own reputation and standing to successfully generate support for having a bricked foot-pavement built on Market Street. Furthermore, he hired a 'poor industrious Man' to sweep the pavement twice a week for six pence per month, to be paid by each house located along the pavement. He convinced the neighborhood to support his plan by publishing a paper that detailed the great advantages resulting from such a small investment, and he listed 'the greater Ease in keeping our Houses clean, so much Dirt not being brought in by People's Feet; the Benefit to the Shops by more Custom, as Buyers could more easily get at them, and by not having in windy Weather the Dust blown in upon their Goods, etc., etc.' As the 'Cleanliness of the Pavement' surrounding the market was a 'Convenience to all,' Franklin writes, a 'general Desire' emerged 'to have all the Streets paved; and made the People more willing to submit to a Tax for that purpose.' 
This episode shows how in Franklin's ideal of the civic man self-interest and the public interest are inseparably intertwined. Franklin envisioned a society of free, self-determined, and moral citizens who, in pursuing their private interests, were voluntarily also contributing to the public good. It is a society in which the pursuit of private interests is enveloped and checked by the idea of serving the public at large.

In promoting civic virtue, the educational purpose of Franklin's autobiography was far from being an individual affair. Rather, Franklin sought to reform society through autobiography. His own project of moral self-perfection is but the starting point for a thorough reform of society as such, in which all individuals should act like Franklin did. A society of free and self-determined individuals acting voluntarily on the principles of sincerity and justice, moderation and humility, industry, and frugality would be a society of essentially stable social relationships, a society without fraud, broken promises, and other forms of disruptive social conduct. ${ }^{25}$

In the context of revolutionary America, Franklin's life narrative can be interpreted as an act of identity politics in a situation of uncertainty that aims at constructing the normative ideal of a model citizen for the new republic and its revolutionary experiment in democracy. Franklin's self-reliance and self-determination, his constant quest for moral selfperfection, and his involvement in numerous public improvement projects define the ideal of a private and public conduct that would help consolidate the new American republic and turn its revolutionary experiment into a success not just for Americans but for the whole of mankind. The didactic impulse in Franklin's autobiography is thus thoroughly political and inseparably connected to the project of 'forming a great Number of good Citizens' for America's democracy to whose creation Franklin had contributed so much. ${ }^{26}$

\section{PERPETUATING EUROPEAN INTEGRATION THROUGH AUTOBIOGRAPHY: KONRAD ADENAUER}

Konrad Adenauer, the first chancellor of the Federal Republic of Germany, who held the office for four terms between 1949 and 1963, can be counted among the great transformational leaders in German history. His major claim to fame was his determined policy of Westpolitik that firmly integrated the Federal Republic into the European Union and secured its membership in the Western alliance systems. Adenauer's Westpolitik has been identified as a revolutionary break with German foreign-policy traditions, largely because it forced Germany and the Germans to reposition themselves as an integral part of the Western community of values forged by liberal democracy and free-market capitalism. ${ }^{27}$ 
Adenauer's Westpolitik was highly controversial among contemporaries for many reasons. German nationalists argued that the Federal Republic's integration into the West first caused and then perpetuated the division of Germany. Others opposed the re-militarization of the Federal Republic that went hand in hand with the Federal Republic's membership in NATO; again others suggested that West Germany's integration into international organizations implied accepting the permanent reduction of its sovereignty as a nation-state. Finally, in terms of identity politics, Adenauer's political stance invalidated all notions of German identity that had pitted Germany, Germans and German Kultur against a Western civilization as defined by the liberal market democracies of the United States, Great Britain, and France. ${ }^{28}$

When Adenauer left office in 1963, he was deeply worried about the future of his Westpolitik agenda. He had defined it as the Federal Republic's reason of state, he remained convinced that it was the only path to lasting peace, security and prosperity for West Germany, and the Western world, and he was certain that it laid the foundations for the anticipated re-unification of Germany in freedom, democracy and free-market capitalism. At the same time, he was nervously uncertain whether his successors in office, the population of West Germany, and the West European allies would continue to accept and pursue his visionary Westpolitik. Political opponents to his course continued to advocate a neutralized Germany between the blocks as they had done throughout the 1950s. In Germany, there was widespread distrust of West European governments, just as West European governments continued to deeply distrust Germany. At the same time, the process of European integration, after an extremely dynamic start in the $1950 \mathrm{~s}$, had begun to slow down and threatened to stagnate altogether.

In this constellation, Adenauer began writing his political memoirs basically upon leaving the office as chancellor of the Federal Republic of Germany. Appearing in four volumes between 1965 and 1968, with the last one published posthumously, Adenauer's political memoirs are utterly boring. For the most part, they are hardly more than a compilation of and an ongoing commentary on decisions taken, laws passed, and treaties signed. Only in few passages does Adenauer offer glimpses into his life's experiences; his subjective household of perceptions, values, convictions, and emotions; or the story of his personality. These more genuinely autobiographical passages are largely confined to the first volume of his memoirs; they describe the situation of 1945, the period of Allied occupation, and the rough beginnings of the Federal Republic of Germany. Yet, despite their overall tediousness, Adenauer's memoirs were written and can be read as an urgent call for a continuation of his Westpolitik. 
This becomes obvious when the consciousness of epoch that carries his autobiographical narrative is reconstructed. It is anchored in the deep historical caesura of the year 1945, which Adenauer autobiographically constructs as both a historical and biographical break separating his own life and the history of Germany into two distinct and unbridgeable phases - one to 1945 , the other since 1945 . The caesura of 1945 separates the present that Adenauer still sees himself living and acting in, from a past that he also experienced but no longer can relate to. Thus, 1945 marks the destruction of the past and the beginning of a new time that is both historically and biographically defined.

Adenauer's political recollections begin in the winter of 1944. The first chapter narrates in great personal detail his release from a concentration camp and the end of World War II as he experienced it in his home in Rhöndorf near Bonn. His autobiographical narrative, thus, links his personal liberation from a prison camp to the liberation of Germany from National Socialism to define the beginning of a present that he saw still lasting when he wrote his memoirs. Adenauer writes: 'This book begins with what followed Germany's collapse in the year of 1945. ${ }^{29}$

What, however, defines the time beginning with 1945 as new in Adenauer's autobiographical diagnosis? What are the markers and indicators of this autobiographical consciousness of epoch? Five elements stand out:

(1) 1945 as a Tabula Rasa

In Adenauer's periodization, the year of 1945 marks in a very fundamental sense the breakdown of the world as he knew it. It stands for the deepest, life-changing caesura he had ever experienced. How deep the experienced break actually was becomes manifest in those instances, where he compares the situation of 1945 with that of the years from 1918 to 1924, which he had already experienced as extremely troubling, burdensome, and disruptive. Germany's situation in 1945, he wrote, was 'incomparably tougher and darker' than the first postwar years after $1918 .{ }^{30}$

In his memoirs, Adenauer constructs the end of World War II as a tabula rasa situation, as return to a primordial state of primitiveness. Its most obvious manifestation is the omnipresent material destruction that he so graphically describes in one of the most gripping passages of his memoirs. In it, Adenauer recollects how he drove through the fields of rubble in Cologne. The rubble landscape of the city does not only symbolize the death and material destruction wrought by World War II, it also symbolizes the complete collapse of all social and political order, the destruction of mental maps, and the total loss of all historical orientation. 'The image of the destroyed city of Cologne was distressing,' Adenauer writes. The 
extent of the war damages was 'outrageous,' he comments and then goes on to detail: 'There was no gas, no water, no electricity. Furthermore, there was no public transportation. The bridges crossing the Rhine river were destroyed. Rubble lay meters high in the streets.' The war thus had undone all progress in terms of civilization; Germans had literally been bombed back into a pre-historic state. To reflect on the complete destruction of tradition and historical continuity, Adenauer uses the example of the churches, which had always marked the presence of the middle ages in his own lifeworld. He writes: 'With its destroyed churches, many of which had been standing for almost a thousand years, with its raped cathedral, with the rubble of formerly beautiful bridges sticking out of the Rhine river, and with its endless sea of destroyed houses, Cologne looked eerie. ${ }^{31}$

This experience of destruction was shaking in a very fundamental sense insofar as for Adenauer there could not possibly be a path back into a before, however defined. His autobiographical diagnosis of the time suggests that such a situation demanded a complete break with the past and all German traditions. In another context, Adenauer said: 'A fall into the abyss, as it befell us Germans, forces one to realize, that one has to break with what was. We cannot lead a fruitful life with lost illusions.' ${ }^{32}$ One central theme defining the 'fall into the abyss' was the end of German statehood, which is the second factor of Adenauer's autobiographical consciousness of epoch.

\section{(2) The Loss of German Statehood}

The end of German statehood resulting from the unconditional surrender of Nazi Germany, was a major factor defining the novelty of the epoch since 1945 in Adenauer's subjective periodization. He stresses that, in his youth, Germany had been among the mightiest states in the world. Around 1900, he writes, the German Reich had appeared 'so strong and stable' like no other European state of that age. ${ }^{33}$ When Adenauer points out that, forty-five years later, this state did no longer exist, he does not so much mourn the loss of the nation-state as the loss of state sovereignty. The experience of total defeat, the Allied take-over of all government authority during the period of occupation, and finally the division of Germany defined a state of permanent exception for Adenauer, which would only end the moment that Germany regained full statehood. Sovereignty, thus, became the marker of a normalcy that Adenauer himself had experienced prior to 1945, that had vanished with Germany's military collapse, and that would only return once the German state could determine itself again. Every German government, Adenauer writes, had to 
struggle to make Germany 'a free, self-determined factor in international relations again.'34 This striving for political self-determination should, however, not be mistaken for an attempt to restore a strong German nation-state. Quite contrary, Adenauer was convinced that nation-states were an anachronism in the post- 1945 world.

\section{(3) The Nation-state as Anachronism}

The world after 1945, for Adenauer, was a thoroughly post-national one. In a speech delivered to the American Committee on United Europe on April 16, 1953, the German chancellor spoke about the 'truly revolutionary necessity' of overcoming the idea of the nation as the highest value; and, in the first volume of his memoirs he states: 'In Europe, we had to get away from thinking in nationalist terms. ${ }^{35}$ Nationalism, thus, appeared as a phenomenon of the nineteenth and the first half of the twentieth century that was to have no place in the post-1945 world. ${ }^{36}$

Two strands of experienced historical change crossed in Adenauer's diagnosis of the nation-state as anachronism. First, he was convinced that an excessive nationalism had caused the catastrophic course of the twentieth century, which is why it needed to be overcome in the post1945 world. Second, Adenauer felt the rapidly accelerating technological change by the 1950s had created a world so radically different from the one of around 1900 that the nation-state no longer appeared as a functional form of political organization capable of solving the problems of the epoch.

In his autobiographical diagnosis Adenauer explains the destructive history of the twentieth century with the primacy of nationalism and the nation-state. In his view, German nationalism and the Prussian concept of an all-powerful state merged into a destructive alliance with the foundation of the German Empire in 1871. This had engrained in Germany's political culture a widely shared belief in the omnipotence of the nationstate. An excessive German nationalism in combination with a deification of an abstract state, in Adenauer's interpretation, produced a historical dynamic that culminated in the Third Reich. ${ }^{37}$ For Adenauer, therefore, a renaissance of nationalism and a renewed omnipotence of the state were to be prevented at all costs, because both bore the seed of new international conflicts and wars.

Nationalism's systemic potential for destruction, however, is not the whole story behind Adenauer's portrayal of the nation-state as an anachronism. Just as important are the rapidly accelerating technological innovation and the industrial transformation of the world, which let national borders become porous and created problems that could no longer be solved in the framework of the nation-state. Reflecting on the many 
fundamental transformations he witnessed in his lifetime, Adenauer once said:

\footnotetext{
'What powerful changes have taken place over the last decades - what leaps? Leaving the political transformations aside for a moment: Barely forty years since the first flight across the Atlantic - and today? Rockets to the moon! In my youth the first gramophone - today devices not bigger than a matchbox that allow you to hear what is being spoken over great distances and through the thickest of walls. ... It is as if everything in our poor world is going awry. This enormous technological change. ${ }^{38}$
}

The technological civilization of an increasingly interdependent and globalizing world, in Adenauer's view, had done its share in invalidating the nation-state as a normative model of political, social, and economic organization. New forms of political organization had to be found.

\section{(4) The Cold War Constellation as Historical Novelty}

The fourth element constituting Adenauer's autobiographical consciousness of epoch is the constellation of the Cold War. ${ }^{39}$ Adenauer reflects the formation of a bi-polar world from the ashes of the Eurocentric world he lived in before 1945, as unprecedented. Already in the summer of 1945, he saw himself facing a new kind of conflict: the systems antagonism of the Cold War, whose frontlines went right through Germany. ${ }^{40}$ This conflict was one between liberal democracy and totalitarian dictatorship Communist-style; one between free-market capitalism and planned economies; and one between the open, pluralistic societies of the West and the closed, proletarian societies of the Soviet world.

In addition to these secular factors, Adenauer's analysis of the East-West conflict is enveloped by a Christian providentialism that sees the U.S.S.R. not only as a totalitarian dictatorship but also as an atheist power. ${ }^{41}$ In this context, Adenauer highlights many structural analogies between the two totalitarian orders of the Third Reich and the Soviet Union. The Third Reich, for Adenauer, had demonstrated for all the world to see what an atheist totalitarian state, unchecked by Christian ethics and humanism, was capable of. ${ }^{42}$ In West Germany, founded from the spirit of Christianity, humanism, and liberalism, totalitarian atheism had been overcome, not least thanks to Adenauer's Westpolitik. Eastern Europe, however, was still living under an anti-bourgeois, totalitarian, and atheist regime; Eastern and Western Europe were literally living in different times. ${ }^{43}$

From this constellation emerged threats that were specific to the epoch as diagnosed by Adenauer himself. Explicitly embracing Winston Churchill's idea of an 'iron curtain,' the first West German chancellor showed himself convinced that Germany and Western Europe could be 
overrun by the Soviet Union any time. ${ }^{44}$ Characterizing relentless and deadly Soviet aggression as the 'danger of our epoch,' Adenauer made it clear that this danger was not only a military one; it was also a religious threat insofar as Soviet atheism threatened European civilization as such..$^{45}$ Adenauer's diagnosis of the bi-polar world as novelty was thus inseparably connected to a realistic view on Europe's decline, which marked the fifth element of Adenauer's consciousness of epoch.

(5) Europe's Decline

Adenauer experienced the self-destruction of Europe and the end of a world in which Europe was the political, economic, and cultural center, within his own lifetime. In Adenauer's view, Europe had ceased to be a power factor in the world. He states that both world wars had originated as European wars, with the largest destruction wrought in the European heartlands. Europe's situation and position in the world had fundamentally changed since 1900. While the United States of America and the Soviet Union had risen to superpower status, the political and economic importance of Europe had declined. ${ }^{46}$ Adenauer stressed how he himself had experienced how Europe had been the center of world politics before 1914. After 1945, Europe had ceased to be an independent and powerful unit. Due to its nationalism-driven self-destruction, it had broken down, was divided and politically impotent between the two new superpowers at what used to be the margins of the Eurocentric world ${ }^{47}$ In a 1954 article written for LIFE magazine, Adenauer let American readers know what reflections were triggered in him when looking at the last map of an historical atlas published in Germany in 1953. It was a very interesting book, Adenauer wrote. The historical maps collected in the atlas demonstrated the deep politico-ideological and cultural transformations of the twentieth century much more directly and graphically than any written history book could ever do.

\footnotetext{
'The contemplation of the last maps made you feel especially solemn. They demonstrated in a rousing way, how freedom was continuously pushed back by the colossus of Soviet-Russian communism that denies freedom on principle and from deepest conviction. Small the space on the Euro-Asian land mass has become, in which freedom still reigns, alarmingly small is Europe itself, ever since the power of Soviet Russia has reached the Elbe river. ${ }^{4} 8$
}

Communism, atheism, totalitarianism, and the Asiatic mingle to construct the notion of an ideologically and emotionally defined evil that is projected onto the Soviet Union which denied everything that defined Europe in Adenauer's view. The redrawing of borders in Europe, for Adenauer, demonstrated the marginalization of Europe in a global context. In the 
summer of 1947, Adenauer thus said: 'Europe is in danger of becoming an appendix of Asia and of losing its leading role in history and cultural developments. ${ }^{49}$ Europe's self-destruction in the wars of the twentieth century, in Adenauer's subjective experience, thus, had led to Asia beginning at the Elbe river.

From this both biographically and historically substantiated analysis of the epoch, Adenauer once more identified the basic task of this 'dangerous period for Europe, and even for mankind,' and this was the defense battle against Soviet communism and the Asiatic peril. The binary alternative resulting from this pointed consciousness of epoch for Adenauer was simple: Every European, he suggested to the readers of the already mentioned 1954 article in LIFE magazine, should know "that for Europe, and for every single European country there is only an either-or! Either the European countries integrate into a unit, or they become extinct; there is no third option. ${ }^{50}$

From this consciousness of epoch grew Adenauer's determination to pursue his agenda of Westpolitik. The breakdown of the world as he knew it and the formation of a new world with its own specific hopes and threats for him offered the chance of starting something daringly new; but, it also demanded it from the political decision makers. Adenauer left no doubt that European integration was key to mastering the challenges of the epoch and to creating a world without wars and want.

In his political memoirs, there is really a one-on-one relation between the problems diagnosed and European integration as a future-oriented solution to all of them. European integration would overcome the destructions and devastations wrought by World War II, and thereby replace the tabula rasa situation of the immediate post-war world with landscapes of prosperity. European integration would be a way for Germany to regain its sovereign statehood and reunite in liberty, democracy, and free-market capitalism. The process of European integration would force all states to give up some of their sovereignty and find new forms of political organization outside and beyond the nation-state. Connected to that is the conviction that European integration would offer a chance to ban the destructive forces of nationalism, while at the same time containing the Soviet Union and ensuring Europe's survival and continued influence in the world.

All depended, however, on the question of whether the acting politicians managed to move the process of European integration to a point beyond return - and Adenauer was deeply worried about that. Seen against this backdrop, Adenauer's memoirs are a political legacy and an urgent call to continue the process of European integration even beyond the endings of his chancellorship, his memoirs, and his death. 


\section{CONCLUSION}

This article has read autobiographical texts of two politicians one would usually not think of comparing as acts of political communication, whose temporal semantics extended well beyond the endings of the texts and the lives of their authors. To unearth the complex communicative pragmatics of both autobiographies, we took the consciousness of epoch carrying the autobiographical narrative as analytical point of departure. As a category of both historical and autobiographical time, consciousness of epoch relates to one another the past and the future from the perspective of the present in which an autobiography is written. Imaginaries of the future are thus written into every (political) autobiography, even if the future is not explicitly thematized.

To unearth the presence of the future in autobiographical recollections of the past, it was necessary to analyze the What of the autobiographical communication in relation to its When, Where, and Why. This required identifying the biographical moment of the autobiographical act as precisely as possible, and embedding it as conscientiously as possible into the political, social, economic, and cultural contexts in which it took place. This approach allowed us to understand Franklin's and Adenauer's autobiographical texts as the future-oriented continuation of politics by autobiographical means. As such, both works were to function well beyond the endings of the autobiographical texts.

\section{BIBLIOGRAPHY}

Adams, Willi Paul. The First American Constitutions: Republican Ideology and the Making of the State Constitutions in the Revolutionary Era. Lanham, MD: Rowman and Littlefield, 2001.

Adenauer, Konrad. Erinnerungen 1945-1963. 4 vols. Stuttgart: DVA, 1965-1968.

Anderson, Douglas. The Unfinished Life of Benjamin Franklin. Baltimore: Johns Hopkins University Press, 2012.

Ball, Simon J. The Cold War: An International History, 1947-1991. London: Arnold, 1998.

Bismarck, Otto von. Gedanken und Erinnerungen. Michael Epkenhans and Eberhard Kolb (eds.). Paderborn: Ferdinand Schöningh, 2012.

Blumenberg, Hans. Die Legitimität der Neuzeit. Frankfurt/Main: Suhrkamp, 1996.

Bosbach, Franz and Magnus Brechtken (eds.). Politische Memoiren in deutscher und britischer Perspektive. Munich: Saur, 2005.

Brechtken, Magnus (ed.). Life Writing and Political Memoir - Lebenszeugnisse und Politische Memoiren. Göttingen: V\&R Unipress, 2012.

Cawelti, John G. Apostles of the Self-Made Man. Chicago: University of Chicago Press, 1965.

Churchill, Winston. The Second World War. 6 vols. London: Weidenfeld and Nicolson, 19481954.

Cogliano, Francis D. Revolutionary America 1763-1815: A Political History. $3^{\text {rd }}$ ed. New York: Routledge, 2017.

Decker, Jeffrey Louis. Made in America: Self-Styled Success from Horatio Alger to Oprah Winfrey. Minneapolis: University of Minnesota Press, 1997. 
Depkat, Volker. Lebenswenden und Zeitenwenden: Deutsche Politiker und die Erfahrungen des 20. Jahrhunderts. Munich: Oldenbourg, 2007.

Depkat, Volker. 'Die Erfindung der republikanischen Präsidentschaft im Zeichen des Geschichtsbruchs: George Washington und die Ausformung eines demokratischen Herrscherbildes.' Zeitschrift für Geschichtswissenschaft 56 (2008) 728-742.

Depkat, Volker. 'Die Politik der europäischen Integration als Ergebnis einer erfahrenen Zeitenwende - Konrad Adenauer.' In: Volker Depkat and Piero S. Graglia (eds.), Entscheidung für Europa: Erfahrung, Zeitgeist und politische Herausforderungen am Beginn der europäischen Integration/Decidere l'Europa: Esperienza, mentalità e sfide politiche agli albori dell'integrazione europea. Tübingen: Niemeyer, 2010, 169-187.

Depkat, Volker. 'Benjamin Franklin: The Autobiography of Benjamin Franklin (1791 sq.).' In: Martina Wagner-Egelhaaf (ed.), Handbook of Autobiography/Autofiction: Volume III: Exemplary Autobiographical/Autofictional Texts. Berlin/Boston: De Gruyter, 2019, 1539-1553.

Egerton, George (ed.). Political Memoir: Essays on the Politics of Memory. London: F. Cass, 1994.

Franklin, Benjamin, Benjamin Franklin's Autobiography. Joyce E. Chaplin (ed.). New York: W.W. Norton, 2012.

Hacke, Christian. Die Außenpolitik der Bundesrepublik Deutschland: Von Konrad Adenauer bis Gerhard Schröder. Berlin: Ullstein, 2003.

Heidenking, Jürgen. The Constitution before the Judgment Seat: The Prehistory and Ratification of the American Constitution, 1787-1791. Charlottesville, VA: University of Virginia Press, 2012.

Heideking, Jürgen and James A. Henretta (eds.). Republicanism and Liberalism in America and the German States, 1750-1850. Cambridge: Cambrige University Press and Washington, DC: German Historical Institute, 2002.

Junker, Detlef (ed.). Die USA und Deutschland im Zeitalter des Kalten Krieges 1945-1990: Ein Handbuch. 2 vols. Stuttgart: DVA, 2001.

Kaelble, Hartmut. Europäer über Europa: Die Entstehung des europäischen Selbstverständnisses im 19. und 20. Jahrhundert. Frankfurt/Main: Campus, 2001.

Koselleck, Reinhart. Vergangene Zukunft: Zur Semantik geschichtlicher Zeiten. Frankfurt/Main: Suhrkamp, 1979.

Koselleck, Reinhart and Reinhart Herzog (eds.). Epochenschwelle und Epochenbewusstsein. Munich: Fink, 1987.

Koselleck, Reinhart. Zeitschichten: Studien zur Historik. Frankfurt/Main: Suhrkamp, 2000a.

Koselleck, Reinhart. 'Die Verzeitlichung der Utopie.' In: Reinhart Koselleck (ed.), Zeitschichten: Studien zur Historik. Frankfurt/Main: Suhrkamp, 2000b, 131-149.

Kottak, Conrad P. The Mirror for Humanity: A Concise Introduction to Cultural Anthropology. $12^{\text {th }}$ ed. New York: McGraw-Hill, 2019.

Lejeune, Philippe. 'The autobiographical pact.' In: Philippe Lejeune and John Paul Eakin (eds.), On Autobiography. Minneapolis: University of Minnesota Press, 1989, 3-30.

Lemay, J. A. Leo. 'Benjamin Franklin, Universal Genius.' In: Leo J. A. Lemay and George Sebastian Rousseau (eds.), The Renaissance Man in the Eighteenth Century: Papers Read at a Clark Library Seminar, 9 October 1976. Los Angeles: William Andrews Clark Memorial Library, 1978, 1-44.

Lemay, J. A. Leo. The Life of Benjamin Franklin. 3 vols. Philadelphia, PA: University of Pennsylvania Press, 2006-2009.

Luhmann, Niklas. Die Gesellschaft der Gesellschaft. Frankfurt/Main: Suhrkamp, 1997.

Morgan, Edmund S. Benjamin Franklin. New Haven: Yale University Press, 2002.

Nora, Pierre. 'Die Staatsmemoiren von Commynes bis de Gaulle.' In: Pierre Nora, Zwischen Geschichte und Gedächtnis. Frankfurt/Main: Fischer, 1998, 96-137.

Overhoff, Jürgen. Benjamin Franklin: Erfinder, Freigeist, Staatenlenker. Stuttgart: Klett Cotta, 2006.

Paine, Thomas. Common Sense, The Rights of Man, and other Essential Writings. New York: Signet Classics, 2003. 
Pocock, J. G. A. The Machiavellian Moment: Florentine Political Thought and the Atlantic Republican Tradition. Princeton, NJ: Princeton University Press, 1975.

Poppinga, Anneliese. Meine Erinnerungen an Konrad Adenauer. Stuttgart: DVA, 1970.

Sargent, Lyman Tower. Utopianism: A Very Short Introduction. Oxford: Oxford University Press, 2010.

Schildt, Axel. Zwischen Abendland und Amerika: Studien zur Westdeutschen Ideenlandschaft der 50er Jahre. Munich: Oldenbourg, 1999.

Schwarz, Hans-Peter. 'Die Politik der Westbindung oder die Staatsräson der Bundesrepublik.' Zeitschrift für Politik 22:4 (1975) 307-337.

Slack, Kevin. Benjamin Franklin, Natural Right, and the Art of Virtue. Rochester: Rochester University Press, 2017.

Trautsch, Jasper M. 'The Invention of the "West".' Bulletin of the German Historical Institute 53 (Fall 2013) 89-102.

Trunk, Achim. Europa, ein Ausweg: Politische Eliten und europäische Identität in den 1950er Jahren. Munich: Oldenbourg, 2007.

Washington, George. 'First Inaugural Address of George Washington.' In: The Avalon Project: Documents in Law, History and Diplomacy, 2008, https://avalon.law.yale.edu/18th_century/wash1.asp. Date accessed: 15 January 2020.

Weber, Max. Die protestantische Ethik I: Eine Aufsatzsammlung. Johannes Winckelmann (ed.), $9^{\text {th }}$ ed. Gütersloh: Gütersloher Verlagshaus Mohn, 2000.

Weidenfeld, Werner. Konrad Adenauer und Europa: Die geistigen Grundlagen der westeuropäischen Integrationspolitik des ersten Bonner Bundeskanzlers. Bonn: Europa Union Verlag, 1976.

Wellenreuther, Hermann. Von Chaos und Krieg zu Ordnung und Frieden: Der Amerikanischen Revolution erster Teil, 1775-1783. Berlin: LIT, 2006.

Wellenreuther, Hermann. Von der Konföderation zur Amerikanischen Nation: Der Amerikanischen Revolution zweiter Teil, 1783-1796. Münster: LIT, 2016.

Westad, Odd A. The Cold War: A World History. New York: Basic Books, 2017.

Winkler, Heinrich August. Der lange Weg nach Westen: Erster Band: Deutsche Geschichte vom Ende des Alten Reiches bis zum Untergang der Weimarer Republik. München: Beck, 2000a.

Winkler, Heinrich August. Der lange Weg nach Westen: Zweiter Band: Deutsche Geschichte vom Dritten Reich bis zur Wiedervereinigung. München: Beck, 2000b.

Wood, Gordon S. The Creation of the American Republic 1776-1787. Chapel Hill, NC: University of North Carolina Press, 1969.

Wright, Louis B. 'Franklin's Legacy to the Gilded Age.' Virginia Quarterly Review 22:2 (1946) 268-279.

Xia, Jingfeng. 'An Anthropological Emic-Etic Perspective on Open Access Practices.' Journal of Documentation 67:1 (2011) 75-94.

\section{ABOUT THE AUTHOR}

Volker Depkat is a trained historian and Professor of American Studies at the University of Regensburg. One of his major research interests is defined by the question of how historians can tap life writing as historical sources. Recently, he has also been moving into the field of biography studies. His publications include Lebenswenden und Zeitenwenden: Deutsche Politiker und die Erfahrungen des 20. Jahrhunderts (Oldenbourg 2007), 'Doing Identity: Auto/Biographien als Akte sozialer Kommunikation,' in Imperial Subjects: Autobiographische Praxis in den Vielvölkerreichen der 
Romanovs, Habsburger und Osmanen im 19. und frühen 20. Jahrhundert, ed. by Martin Aust and Frithjof Benjamin Schenk (Böhlau 2015, 39-58) as well as several contributions to Martina Wagner-Egelhaaf's Handbook of Autobiography/Autofiction (De Gruyter 2020). Email: volker.depkat@ur.de.

\section{NOTES}

1 Lejeune, Philippe. 'The autobiographical pact.' In: Philippe Lejeune and John Paul Eakin (eds.), On Autobiography. Minneapolis: University of Minnesota Press, 1989, 4.

2 Koselleck, Reinhart. Vergangene Zukunft: Zur Semantik geschichtlicher Zeiten. Frankfurt/ Main: Suhrkamp, 1979; Koselleck, Reinhart. Zeitschichten: Studien zur Historik. Frankfurt/ Main: Suhrkamp, 2000a; Luhmann, Niklas. Die Gesellschaft der Gesellschaft. Frankfurt/Main: Suhrkamp, 1997, 997-1016.

3 Bismarck, Otto von. Gedanken und Erinnerungen. Michael Epkenhans and Eberhard Kolb (eds.). Paderborn: Ferdinand Schöningh, 2012; Churchill, Winston. The Second World War. 6 vols. London: Weidenfeld and Nicolson, 1948-1954; Nora, Pierre. 'Die Staatsmemoiren von Commynes bis de Gaulle.' In: Pierre Nora. Zwischen Geschichte und Gedächtnis. Frankfurt/Main: Fischer, 1998, 96-137. On political memoir as a genre: George Egerton (ed.). Political Memoir: Essays on the Politics of Memory. London: F. Cass, 1994; Bosbach, Franz and Magnus Brechtken (eds.). Politische Memoiren in deutscher und britischer Perspektive. München: Saur, 2005; Brechtken, Magnus (ed.). Life Writing and Political Memoir - Lebenszeugnisse und Politische Memoiren. Göttingen: V\&R Unipress, 2012.

4 For a detailed elaboration on this approach see Depkat, Volker. Lebenswenden und Zeitenwenden: Deutsche Politiker und die Erfahrungen des 20. Jahrhunderts. München: Oldenbourg, 2007, 65-253.

5 Kottak, Conrad P. The Mirror for Humanity: A Concise Introduction to Cultural Anthropology. $12^{\text {th }}$ ed. New York: McGraw-Hill, 2019; Xia, Jingfeng. 'An Anthropological Emic-Etic Perspective on Open Access Practices.' Journal of Documentation 67:1 (2011) 75-94.

6 Koselleck, Reinhart. 'Die Verzeitlichung der Utopie.' In: Koselleck, Zeitschichten, 131-149. On the idea and politics of utopia: Sargent, Lyman Tower. Utopianism: A Very Short Introduction. Oxford: Oxford University Press, 2010.

7 Blumenberg, Hans. Die Legitimität der Neuzeit. Frankfurt/Main: Suhrkamp, 1996; Koselleck, Reinhart and Reinhart Herzog (eds.). Epochenschwelle und Epochenbewusstsein. München: Fink, 1987. Depkat, Lebenswenden und Zeitenwenden, 129-253 applies consciousness of epoch as a category of autobiographical time.

8 Franklin, Benjamin. Benjamin Franklin's Autobiography. Joyce E. Chaplin (ed.). New York: W.W. Norton, 2012; Adenauer, Konrad. Erinnerungen 1945-1963. 4 vols. Stuttgart: DVA, $1965-1968$.

9 The most detailed biography on Benjamin Franklin is the monumental but uncompleted Lemay, J. A. Leo. The Life of Benjamin Franklin. 3 vols. Philadelphia, PA: University of Pennsylvania Press, 2006-2009. More accessible one-volume biographies were written by Morgan, Edmund S. Benjamin Franklin. New Haven: Yale University Press, 2002, and Overhoff, Jürgen. Benjamin Franklin: Erfinder, Freigeist, Staatenlenker. Stuttgart: Klett Cotta, 2006. The best one-volume introduction to the political history of the American Revolution is Cogliano, Francis D. Revolutionary America 1763-1815: A Political History. $3^{\text {rd }}$ ed. New York: Routledge, 2017. Detailed and magisterial: Wellenreuther, Hermann. Von Chaos und Krieg zu Ordnung und Frieden: Der Amerikanischen Revolution erster Teil, 1775_ 1783. Berlin: LIT, 2006; Wellenreuther, Herman. Von der Konföderation zur Amerikanischen Nation: Der Amerikanischen Revolution zweiter Teil, 1783-1796. Münster: LIT, 2016. 
10 On Washington and how he used his political capital as personification of the American Revolution to consolidate the American republic: Depkat, Volker. 'Die Erfindung der republikanischen Präsidentschaft im Zeichen des Geschichtsbruchs: George Washington und die Ausformung eines demokratischen Herrscherbildes.' Zeitschrift für Geschichtswissenschaft 56 (2008) 728-742.

11 Washington, George. 'First Inaugural Address of George Washington.' The Avalon Project: Documents in Law, History and Diplomacy, 2008, https://avalon.law.yale.edu/18th century/wash1.asp. Date accessed: 15 January 2020. Paine, Thomas. Common Sense, The Rights of Man, and other Essential Writings. New York: Signet Classics, 2003, 59-60.

12 Wood, Gordon S. The Creation of the American Republic 1776-1787. Chapel Hill, NC: University of North Carolina Press, 1969; Adams, Willi Paul. The First American Constitutions: Republican Ideology and the Making of the State Constitutions in the Revolutionary Era. Lanham, MD: Rowman \& Littlefield, 2001; Heidenking, Jürgen. The Constitution before the Judgment Seat: The Prehistory and Ratification of the American Constitution, 1787-1791. Charlottesville, VA: University of Virginia Press, 2012.

13 Washington, 'First Inaugural Address.' Avalon Project.

14 On classical republicanism, see Pocock, J.G.A. The Machiavellian Moment: Florentine Political Thought and the Atlantic Republican Tradition. Princeton, N.J: Princeton University Press, 1975; Heideking, Jürgen and James A. Henretta (eds.). Republicanism and Liberalism in America and the German States, 1750-1850. Cambridge: Cambridge University Press and Washington, D.C: German Historical Institute, 2002.

15 Franklin's social and political thought is analyzed by Slack, Kevin. Benjamin Franklin, Natural Right, and the Art of Virtue. Rochester: Rochester University Press, 2017. On Franklin's own experiences with society and how this relates to his project of moral selfimprovement: Anderson, Douglas. The Unfinished Life of Benjamin Franklin. Baltimore: Johns Hopkins University Press, 2012.

16 Summarizing the complex genesis and structure of Franklin's autobiography: Depkat, Volker. 'Benjamin Franklin: The Autobiography of Benjamin Franklin (1791 sq.).' In: Martin Wagner-Egelhaaf (ed.), Handbook of Autobiography/Autofiction: Volume III: Exemplary Autobiographical/Autofictional Texts. Berlin/Boston: De Gruyter, 2019, 1539-1553.

17 Franklin, Autobiography, 86.

18 Idem, 1.

19 Lemay, J. A. Leo. 'Benjamin Franklin, Universal Genius.' In: Leo J. A. Lemay and George Sebastian Rousseau (eds), The Renaissance Man in the Eighteenth Century: Papers Read at a Clark Library Seminar, 9 October 1976. Los Angeles: William Andrews Clark Memorial Library, 1978, 1-44; Wright, Louis B. 'Franklin's Legacy to the Gilded Age.' Virginia Quarterly Review 22:2 (1946) 268-279; Cawelti, John G. Apostles of the Self-Made Man, Chicago: University of Chicago Press, 1965; Decker, Jeffrey Louis. Made in America: SelfStyled Success from Horatio Alger to Oprah Winfrey. Minneapolis: University of Minnesota Press, 1997.

20 Franklin, Autobiography, 78.

21 Idem, 80.

22 Idem, 86.

23 Weber, Max. Die protestantische Ethik I: Eine Aufsatzsammlung. Johannes Winckelmann (ed.). $9^{\text {th }}$ ed. Gütersloh: Gütersloher Verlagshaus Mohn, 2000, 39-66.

24 Franklin, Autobiography, 117-121.

25 Anderson, Unfinished Life, 33-35, 47-81.

26 Franklin, Autobiography, 91.

27 The following is largely based on Depkat, Volker. 'Die Politik der europäischen Integration als Ergebnis einer erfahrenen Zeitenwende - Konrad Adenauer.' In: Volker Depkat and Piero S. Graglia (eds.). Die Entscheidung für Europa: Erfahrung, Zeitgeist 
und politische Herausforderungen am Beginn der europäischen Integration/Decidere l'Europa: Esperienza, mentalità e sfide politiche agli albori dell'integrazione europea. Tübingen: Niemeyer, 2010, 169-188. On Adenauer's policy of Westintegration and its place in the traditions of German foreign policy: Schwarz, Hans-Peter. 'Die Politik der Westbindung oder die Staatsräson der Bundesrepublik.' Zeitschrift für Politik 22:4 (1975) 307-337. The most thorough study on Adenauer's European policy still is Weidenfeld, Werner. Konrad Adenauer und Europa: Die geistigen Grundlagen der westeuropäischen Integrationspolitik des ersten Bonner Bundeskanzlers. Bonn: Europa Union Verlag, 1976; Hacke, Christian. Die Außenpolitik der Bundesrepublik Deutschland: Von Konrad Adenauer bis Gerhard Schröder. Berlin: Ullstein, 2003, 49-54.

28 On the construction of the West and Germany's place in it see: Trautsch, Jasper M. 'The Invention of the "West". Bulletin of the German Historical Institute 53 (Fall 2013) 89-102; Schildt, Axel. Zwischen Abendland und Amerika: Studien zur Westdeutschen Ideenlandschaft der 50er Jahre. München: Oldenbourg, 1999; Winkler, Heinrich August. Der lange Weg nach Westen: Erster Band: Deutsche Geschichte vom Ende des Alten Reiches bis zum Untergang der Weimarer Republik. München: Beck, 2000a; Winkler, Heinrich August. Der lange Weg nach Westen: Zweiter Band: Deutsche Geschichte vom Dritten Reich bis zur Wiedervereinigung. München: Beck, 2000b.

29 'Mit dem, was dem Zusammenbruch Deutschlands im Jahre 1945 folgte, beginnt dieses Buch.' Adenauer, Erinnerungen, vol. 1, 14.

30 'unvergleichlich viel härter und dunkler'. Idem, 42.

31 'Das Bild der zerstörten Stadt Köln war erschütternd. Das Ausmaß des Schadens ... ungeheuerlich. ... Es gab kein Gas, kein Wasser, keinen elektrischen Strom. Außerdem gab es keine Verkehrsmittel. Die Brücken über den Rhein waren zerstört. Schutt lag in den Straßen meterhoch. ... Köln sah mit seinen zerstörten Kirchen, von denen viele fast tausend Jahre gestanden hatten, mit seinem geschändeten Dom, mit den aus dem Rhein ragenden Trümmern der einst so schönen Brücken und dem unendlichen Meer von zerstörten Häusern gespenstisch aus.' All quotes: Idem, 21.

32 'Ein Sturz in den Abgrund, wie er uns Deutschen widerfuhr, zwingt zu der Einsicht, daß mit dem Gewesenen gebrochen werden muß. Mit verlorenen Illusionen können wir kein fruchtbares Leben führen.' Quoted in Weidenfeld, Adenauer und Europa, 34.

33 '[S] o stark und fest.' Adenauer, Erinnerungen, vol. 1, 43.

34 '[W]ieder zu einem freien, selbständigen Faktor in der Außenpolitik werden zu lassen.' Idem, vol. 2, 63.

35 'Wir mußten in Europa loskommen von dem Denken in nationalstaatlichen Begriffen.' Idem, vol. 1, 563.

36 Cf. also idem, 235.

37 Cf. idem, 44.

38 'Von den politischen Veränderungen jetzt einmal ganz abgesehen: Kaum vierzig Jahre seit dem ersten Flug über den Atlantik - und jetzt? Raketen zum Mond! In meiner Jugend das erste Grammophon - jetzt Geräte nicht größer als eine Streichholzschachtel, mit denen man auf weite Entfernungen hören kann, durch noch so dicke Häuserwände hindurch, was gesprochen wird. ... Es ist, als ob auf unserer armen Erde alles aus den Fugen gerät. Dieser gewaltige technische Fortschritt.' Cited in Poppinga, Anneliese. Meine Erinnerungen an Konrad Adenauer. Stuttgart: DVA, 1970, 258-259.

39 Literature on the Cold War is vast. Especially relevant for the German-American and international dimensions of the Cold War are Junker, Detlef (ed.). Die USA und Deutschland im Zeitalter des Kalten Krieges 1945-1990: Ein Handbuch. 2 vols. Stuttgart: DVA, 2001; Westad, Odd A. The Cold War: A World History. New York: Basic Books, 2017; Ball, Simon J. The Cold War: An International History, 1947-1991. London: Arnold, 1998.

40 Adenauer, Erinnerungen, vol. 2, 17. 
41 Idem, vol. 1, 54, 59; vol. 3, 455 .

42 Idem, vol. 1, 51.

43 Idem, 59.

44 Idem, 91-92.

45 Idem, 114. Cf. Weidenfeld, Adenauer und Europa, 85-86.

46 Adenauer, Erinnerungen, vol. 1, 210.

47 Weidenfeld, Adenauer und Europa, 83-84. The diagnosis of Europe's decline let many European statesmen and politicians support European integration as a means to regain lost strength between the blocs. Trunk, Achim. Europa, ein Ausweg: Politische Eliten und europäische Identität in den 1950er Jahren. München: Oldenbourg, 2007, 140-230; Kaelble, Hartmut. Europäer über Europa: Die Entstehung des europäischen Selbstverständnisses im 19. und 20. Jahrhundert. Frankfurt/Main: Campus, 2001, 128-218.

48 'Besonders ernst stimmt die Betrachtung der letzten Karten. Sie zeigen in aufrüttelnder Weise, wie die Freiheit in Europa immer mehr zurückgedrängt ist durch den Koloß des die Freiheit aus Prinzip, aus innerer Überzeugung verneinenden sowjetrussischen Kommunismus. Klein ist der Raum in der Landmasse Europa-Asien geworden, in dem noch Freiheit herrscht, erschreckend klein ist Europa selbst, seitdem die Macht Sowjetrußlands bis zur Elbe reicht.' Cited in Weidenfeld, Adenauer und Europa, 144. Cf. also: Adenauer, Erinnerungen, vol. 1, 313, 539, 553; vol. 2, 422.

49 'Europa steht in Gefahr, ein Anhängsel von Asien zu werden und die Führung in der Geschichte und der kulturellen Entwicklung zu verlieren.' Cited in Weidenfeld, Adenauer und Europa, 150.

50 'dieser gefahrvollen Periode Europas, ja der Menschheit'. 'Jeder Europäer müsse wissen, daß es für Europa, für jedes europäische Land nur ein Entweder-Oder gibt! Entweder die europäischen Länder schließen sich zu einer Einheit zusammen, oder sie gehen unter, ein drittes gibt es nicht.' Cited in idem, 145. 